\title{
The Hanna Farm pluton, Cobequid Highlands: petrology and significance for motion on the Kirkhill fault
}

\author{
Georgia Pe-Piper and Denise S. Turner \\ Department of Geology, St Mary's University \\ Halifax, Nova Scotia B3H 3 C3 \\ Date Received May 6, 1988 \\ Date Accepted August 16, 1988
}

\begin{abstract}
The Hanna Farm pluton is a complex granite - gabbro pluton which appears to be truncated by the Kirkhill fault zone, probably by predominantly dip-slip motion. A leucogranite has been intruded into the Kirkhill fault zone at the southern end of the Hanna Farm pluton. The main Hanna Farm pluton contains secondary biotite and other evidence of hydrothermal alter ation, and is petrographically and geochemically similar to a series of Early Carboniferous (ca. $345 \mathrm{Ma}$ ) granites in the western Cobequid Highlands. Secondary biotite within country rock has been radiometrically dated at $303 \pm 11 \mathrm{Ma}$. The leucogranite within the Kirkhill fault zone lacks evidence of hydrothermal alteration. It shows local ductile deformation, but is not noticeably offset by the Kirkhill fault zone.

The Kirkhill fault zone is one of the major east-west trending fault zones in the western Cobequid Highlands. It cuts and mylonitises late Hadrynian sedimentary and plutonic rocks, and probable Early Carboniferous plutons. The Hanna Farm pluton appears to post-date the last major phase of strike-slip motion on the Kirkhill fault.
\end{abstract}

Le Pluton de Hanna Farm est un bâti complexe de granite et gabbro que semble recouper la zone de failles de Kirkhill, probablement sous l'effet d'un movement à forte composante selon le rejet-pente. Un leucogranite s'est mis en place au sein de la zone de failles de Kirkhill aux confins méridionaux du Pluton de Hanna Farm. Le pluton principal de Hanna Farm contient une biotite secondaire ainsi que d'autres preuves d'une altération hydrothermale. Il ressemble, par sa pétrographie et son géochimisme, à une série de granites écarboniferes (environ $345 \mathrm{Ma}$ ) de l'ouest des Monts Cobequid. Une datation radiométrique de la biotite secondaire que renferme l'encaissant, la situe à $303 \pm 11 \mathrm{Ma}$. On ne rencontre aucune trace d'altération hydrothermale dans le leucogranite sis au sein de la zone de failles de Kirkhill. Celui-ci présente une déformation ductile locale mais n'est pas décalé de façon notable par la zone de failles de Kirkhill.

Cette dernière est l'une des principales zones de failles à tendance Est-Ouest dans l'ouest des Monts Cobequid. Elle recoupe et mylonitise des roches plutoniques et sédimentaires tardihadryniennes ainsi que des plutons probablement éocarboniferres. Le Pluton de Hanna Farm semble postdater le dernier épisode majeur de décrochement sur la faille de Kirkhill.

[Traduit par le joumal]

\section{INTRODUCTION}

The Hanna Farm pluton is one of a series of Early Carboniferous granitic plutons associated with the Cobequid and Kirkhill faults in the western Cobequid Highlands (Donohoe and Wallace, 1982; Pe-Piper et al., in press). The pluton was originally described by Donohoe (1976) and Clarke et al. (1980), who reported an average composition based on chemical analyses of five samples from the Hanna Farm and other granitic plutons in the western Cobequid Highlands.

The Hanna Farm pluton consists of three distinct units (Fig. 2): gabbro and granophyric alkali-feldspar granite ("main granite") in the main northern part of the pluton; and alkali-feldspar granite lacking plagioclase and biotite ("fault-zone granite") within the Kirkhill fault zone. The main northern part of the pluton has been dated by the whole rock $\mathrm{Rb}$-Sr isochron method at $338 \pm 17 \mathrm{Ma}$ (Pe-Piper et al., in press). The pluton intruded late Hadrynian sedimentary and volcanic rocks of the Jeffers Group and probably also mafic volcanic rocks of the Fountain Lake Group (Fig. 2). The fault-zone granite is cut by the Kirkhill fault zone, with local shearing and recrystallisation of the granite.
The Kirkhill fault zone trends east-west and is situated about $3 \mathrm{~km}$ north of the Cobequid Fault zone in the western Cobequid Highlands (Fig. 1). It is the largest fault in the western Cobequid Highlands north of the Cobequid Fault, and may represent a continuation of the Rockland Brook Fault in the eastern Cobequid Highlands. Movement on this fault has probably played an important role in the geological evolution of the western Cobequid Highlands. It was originally mapped by ${ }^{\prime}$ Donohoe and Wallace (1982) along Kirkhill Mountain, on both sides of the Diligent River (Fig. 3). Our mapping has extended the trace of this fault for about $12 \mathrm{~km}$ from Kirkhill Mountain eastwards to Davidson Brook, where it is marked by mylonitic plutonic rocks and volcaniclastic sedimentary rocks of the late Hadrynian Jeffers Group. West of Kirkhill Mountain, the fault is onlapped by the Carboniferous Cumberland Group, but farther west in the Fowler Brook inlier it may mark the mylonitised contact of the Jeffers Group with the Apple River pluton to the north and the Devono-Carboniferous Greville River Formation to the south (Fig. 1). East of Davidson Brook, the mylonitically deformed rocks of the Kirkhill fault zone are either onlapped by or in faulted contact with undeformed volcanic rocks of the Fountain Lake 


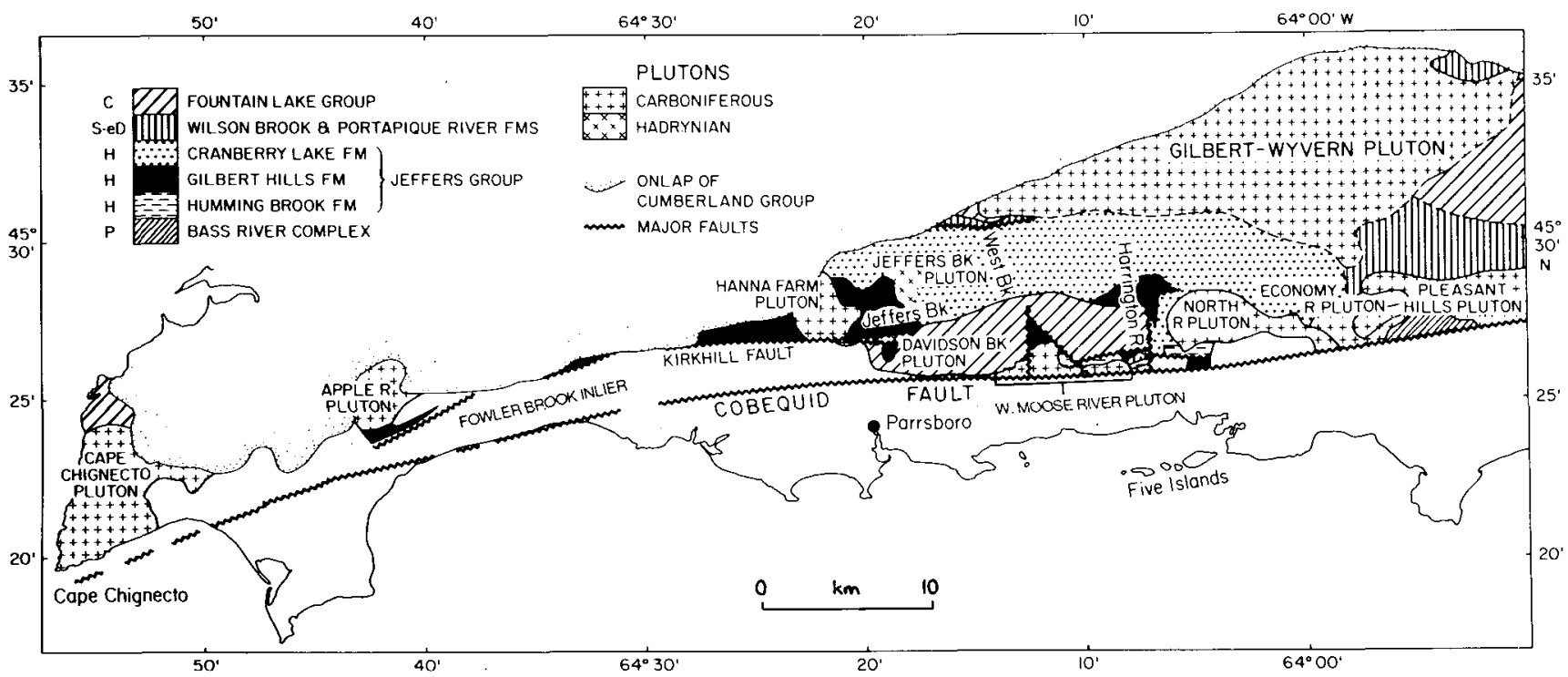

Fig. 1. Map showing regional setting of the Hanna Farm pluton and the Kirkhill fault zone in the western Cobequid Hills. The fault zone can be traced westward from the Davidson Brook pluton for about $20 \mathrm{~km}$, and may re-appear from beneath Cumberland Group cover in the Fowler Brook inlier.

Group, which in this area is of Early Carboniferous age (Cormier, 1982).

The Cobequid Highlands were an area of significant strikeslip motion in Carboniferous times, probably reflecting the docking of the Meguma with the Avalon Terrane of the Appalachians (Keppie, 1982; Donohoe and Wallace, 1985). Most of this displacement was by dextral slip (Eisbacher, 1969, 1970). Yeo and Gao (1987) demonstrated that the Westphalian C to D Stellarton Basin opened as a result of dextral motion on the Hollow and eastern Cobequid faults. In the western Cobequid Highlands, however, there is no good control on the amount of strike-slip motion on the Cobequid and related faults such as the Kirkhill. Donohoe and Wallace (1985) presented evidence for at least $20 \mathrm{~km}$ of dextral motion on the Cobequid Fault following extrusion of the Fountain Lake Group, and at least $80 \mathrm{~km}$ of movement on the Rockland Brook Fault of the eastern Cobequid Highlands since the Early Carboniferous intrusion of the Hart Lake - Byers Lake pluton. The timing of movement on the major faults in the eastern Cobequid Hills is partially constrained by radiometric data; the Rockland Brook Fault mylonitised the Hart Lake-Byers Lake pluton (dated at $348 \pm 5$ Ma by Donohoe et al., 1986), but motion on the fault had ended by the intrusion of the Pleasant Hills pluton, dated at $315 \pm 25 \mathrm{Ma}$ (Cormier, 1979). The supply of coarse detritus northwards from the Cobequid Highlands to the Cumberland Basin has been used by Ryan et al. (1987) to identify times of uplift in the region. They recognised three major periods of uplift, in the mid Devonian, the Late Namurian and the Wesphalian B.

This paper describes the petrography and geochemistry of the Hanna Farm pluton, as an example of the Early Carboniferous granites in the western Cobequid Highlands. It also examines the evidence provided by the pluton for the timing and style of motion on the Kirkhill fault. This contributes to our understanding of the history of Carboniferous fault movement in the western Cobequid Highlands.

\section{METHODS}

The Hanna Farm pluton and Kirkhill fault zone were mapped at a scale of $1: 10,000$. Much of the pluton is masked by glacial drift; in general, outcrops are restricted to stream sections. Samples were collected for thin section study and chemical analysis.

Representative analyses of all minerals described from the Hanna Farm pluton have been made by electron microprobe (as described by Clarke, 1976). Chemical analyses of representative rocks have been made by X-ray fluorescence: analytical methods are described in detail in Pe-Piper and Piper (in press). Igneous rock nomenclature follows the IUGS nomenclature of Streckeisen (1976).

\section{GEOLOGY OF THE HANNA FARM PLUTON}

The main (northem) part of the Hanna Farm pluton consists of a granophyric alkali-feldspar granite (Table 1), a clinopyroxene-rich gabbro to quartz gabbro (referred to as gabbro in all subsequent discussions and figures), and minor hybrid rocks. The southem part of the pluton within the Kirkhill fault zone consists entirely of alkali-feldspar granite.

The gabbro occurs in two discrete stocks at the margins of the main pluton. The central parts of the mafic bodies are made of homogenous gabbro, whereas hybrid rocks with higher quartz content occur toward the granite contacts.

The hybrid rocks range in composition from granite to gabbro, and tend to grade into the two end members. Texturally, some rocks are completely homogenous whereas others show more mafic and more felsic patches on a hand specimen scale. Field relationships showing that granitic hybrid rocks cut gabbroic hybrid rocks indicate that the gabbroic and granitic magmas were essentially synchronous. However, much of the gabbro is cut by granitic veins, which may indicate that the gabbro is at least 


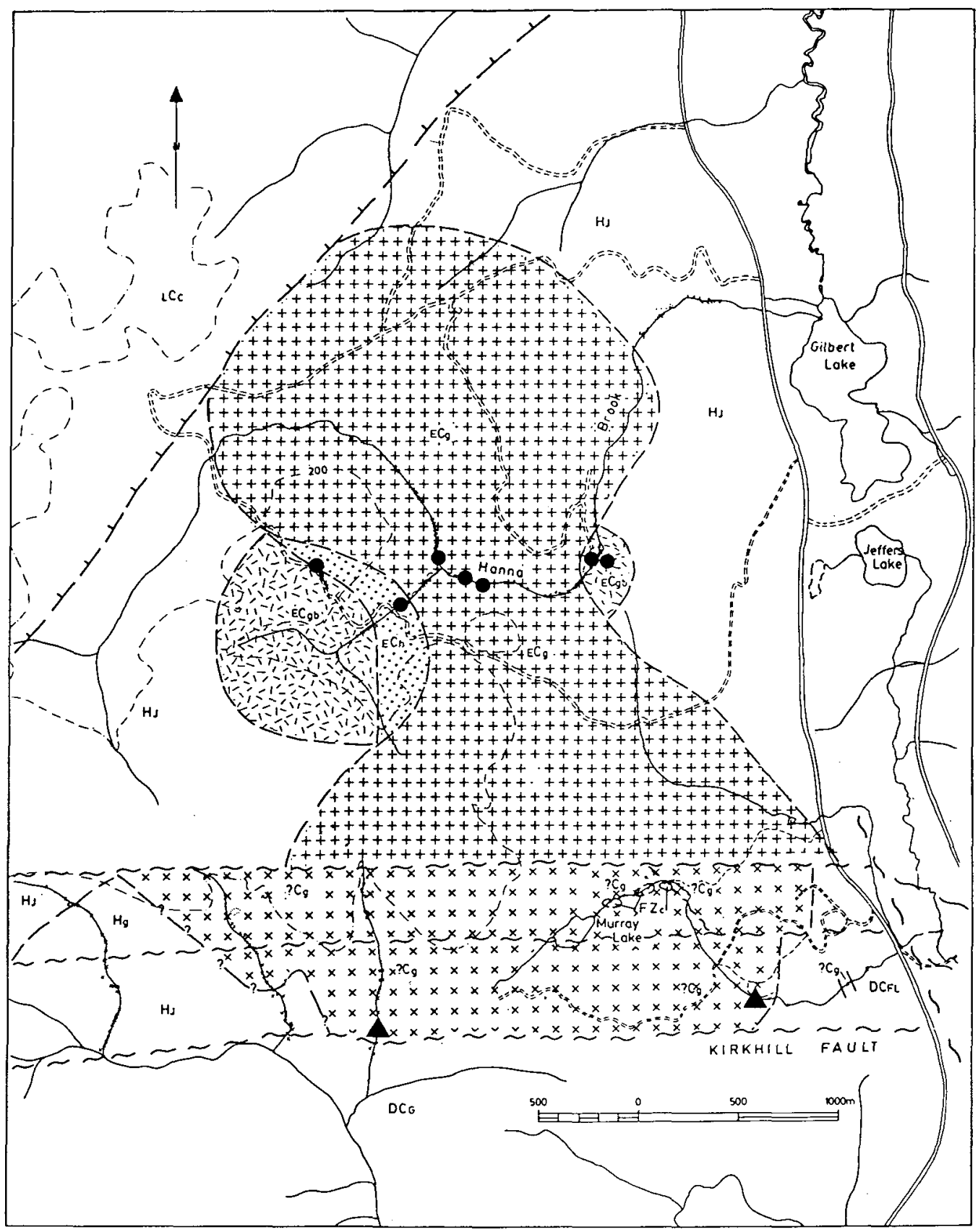

Fig. 2. Geological map of the Hanna Farm pluton. Rock units symbols follow Donohoe and Wallace (1982). Triangles indicate isolated outcrops of $\mathrm{ECg}$ in the Kirkhill fault zone. Solid dots indicate sampling localities.

Late Carboniferous

$L_{c}$ - Cumberland Group: red polymictic conglomerate, wacke.

${ }^{2} \mathrm{C}_{8}$ - deformed leucocratic alkali-feldspar granite.

Early Carboniferous:
EC - pink alkali-feldspar granite.
${E C_{h}^{8}}^{8}$ - hybrid phases.
$\mathrm{EC}_{\mathrm{gb}}$ - gabbro.

Devono-Carboniferous (probably early Carboniferous)

$\mathrm{FZ}_{\mathrm{c}}$ - conglomerate in Cobequid Fault zone, probably proximal.

$\mathrm{DC}_{\mathrm{o}}$ - Greville River Formation: grey, tan quartz wacke, siltstone.

Hadrynian

$\mathrm{DC}_{\mathrm{PL}}$ - Fountain Lake Group: red brown rhyolite.

$\mathrm{H}_{\mathrm{d}}$ - predominantly granodiorite, tonalite; minor diorite, gabbro.

$\mathrm{H}_{\text {g }}$ - granite to granodiorite.

$\mathrm{H}_{\mathrm{J}}^{\mathrm{g}}$ - Jeffers Group: metavolcanic and metasedimentary rocks. 


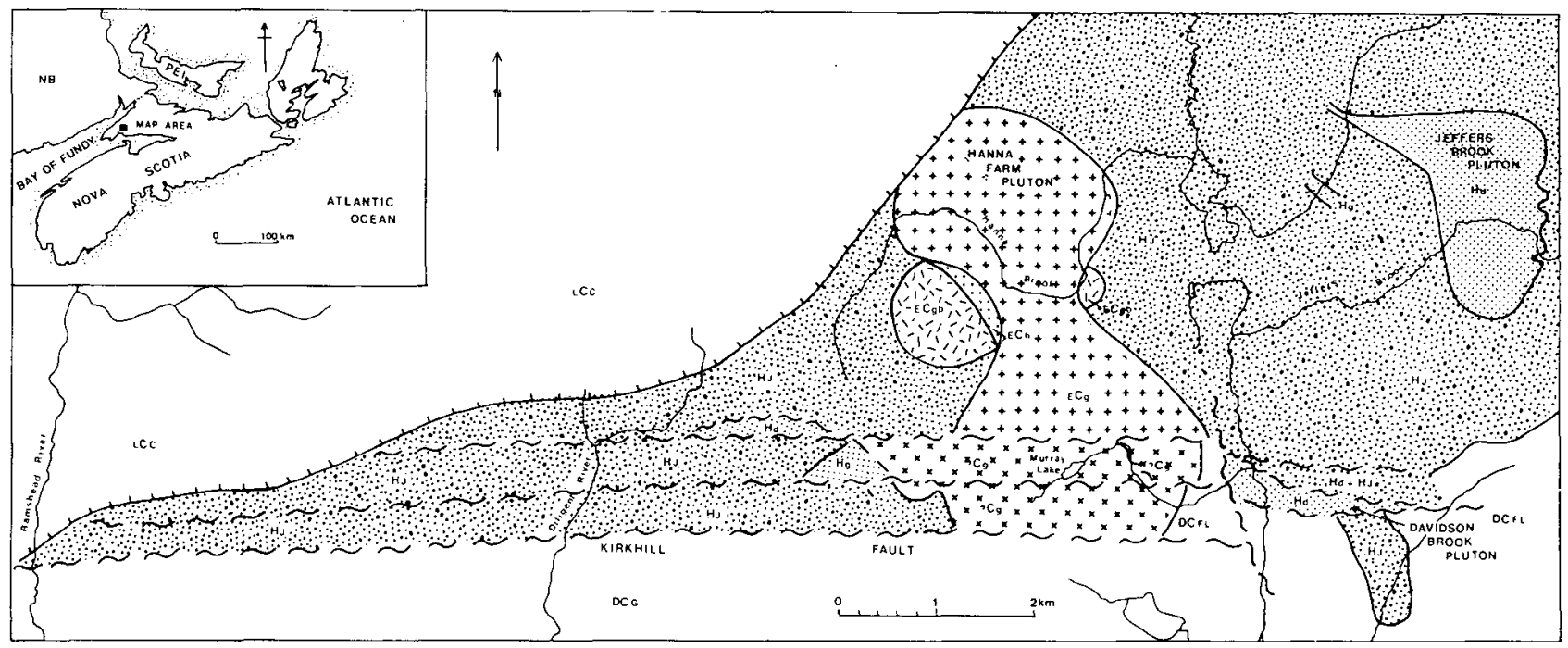

Fig. 3. Map showing Kirkhill fault zone between Ramshead River and Davidson Brook pluton. Rock units as in Figure 2.

slightly older than the granite, and/or that the granitic magma persisted longer.

Within the Kirkhill fault zone, the predominant lithology is a leucocratic porphyroclastic alkali-feldspar granite. All contacts of this granite with other rocks are tectonic. Locally, just north of the southernmost splay of the Kirkhill fault, there are small outcrops of little-deformed granite resembling the granite of the main pluton. (These outcrops are too small to map, but are shown by triangles in Figure 2.) Locally within the fault zone are small outcrops of fine conglomerate with rounded rhyolitic clasts (FZc in Fig. 2), interpreted as a proximal facies of the Greville River Formation. In the same area are a few small tectonised slices of lithologies resembling the Jeffers Group (not distinguished in Figure 2).

\section{PETROLOGY OF THE HANNA FARM PLUTON}

\section{Gabbro}

The gabbro is typically medium-grained and dark gray to greenish in color, with white to greenish plagioclase crystals. Mafic minerals make up $56-66 \%$ of the rock. In thin section, the rock is somewhat altered, making determination of original mineralogy and texture difficult. The texture appears subophitic, with altered plagioclase laths and pseudomorphs of dusty-looking, altered green amphibole after clinopyroxene. Plagioclase is subhedral, variably saussuritized, and forms 30 $33 \%$ of the rock. It is zoned, with an overall range of compositions in most crystals from labradorite $\left(\mathrm{An}_{60}\right)$ to andesine $\left(\mathrm{An}_{34}\right)$. Rare oligoclase rims on andesine and rare albite crystal are probably the result of subsolidus reactions. The amphibole (41$43 \%$ of the rock) is subhedral to anhedral, green to brownishgreen homblende. In places it is intimately mixed with secondary actinolite and dusty opaque minerals. Primary clinopyroxene is very rare. Quartz is not always present and typically varies from $0-5 \%$, increasing toward granitic contacts. It is always interstitial. Brown, probably igneous, biotite is present in small amounts $(<1 \%)$, formed at the expense of amphibole. Some crystals of biotite contain oriented rutile inclusions. Opaque minerals, apatite, epidote, secondary biotite, chlorite and rare secondary sphene are also present.

\section{Alkali-feldspar granite of main pluton}

The main granite north of the Kirkhill fault zone is mediumto coarse-grained, approximately equigranular and pink in color. Rare outcrops of similar granite occur in the southern part of the Kirkhill fault zone. In thin section, this main granite shows varying development of granophyric texture. The granophyre occurs as pod-shaped growths, typically $1-4 \mathrm{~mm}$ in diameter, radiating out from a central nucleus of either feldspar or quartz, and probably represents a magmatic feature. Representative modal analyses are shown in Table 1 . The granophyric granite is composed of $28-34 \%$ anhedral quartz, mainly intergrown with $\mathrm{K}$-feldspar. The K-feldspar (32-48\%) is untwinned orthoclase which occurs as interstitial crystals or as anhedral, perthitic grains. Some of these have replaced plagioclase; others show Rapakivi texture. In most instances, the $\mathrm{K}$-feldspar is only mildly altered to sericite. Plagioclase occurs either in perthite, where it has the composition of albite (about $4-13 \%$ of rock), or as individual grains with undetermined composition $(8-23 \%$ of rock). Limited electron-microprobe data indicate that most or all of these plagioclase crystals are albite. Plagioclase is commonly altered to sericite/epidote and some is preferentially replaced by perthite. Greenish-brown grains of ragged biotite (Plate 1A) make up $<10 \%$ of the rock, occurring as isolated grains, or more commonly in vein-like clotsalong fractures (Plate 1B). The latter biotite is interpreted as being of secondary origin and is discussed in more detail below. Ragged opaque minerals and zircon are accessory minerals. Veinlets of quartz or epidote are common. Evidence of deformation is present in the form of brittle fractures.

Granite located near the gabbro stocks has a higher proportion of biotite and more calcic plagioclase and the plagioclase takes on a dusty alteration. These mineralogical changes suggest that mixing of granitic and more mafic material has occurred. The replacement of plagioclase by perthite may represent a late 
Table 1. Modal compositions of representative granite and gabbro samples from the Hanna Farm pluton.

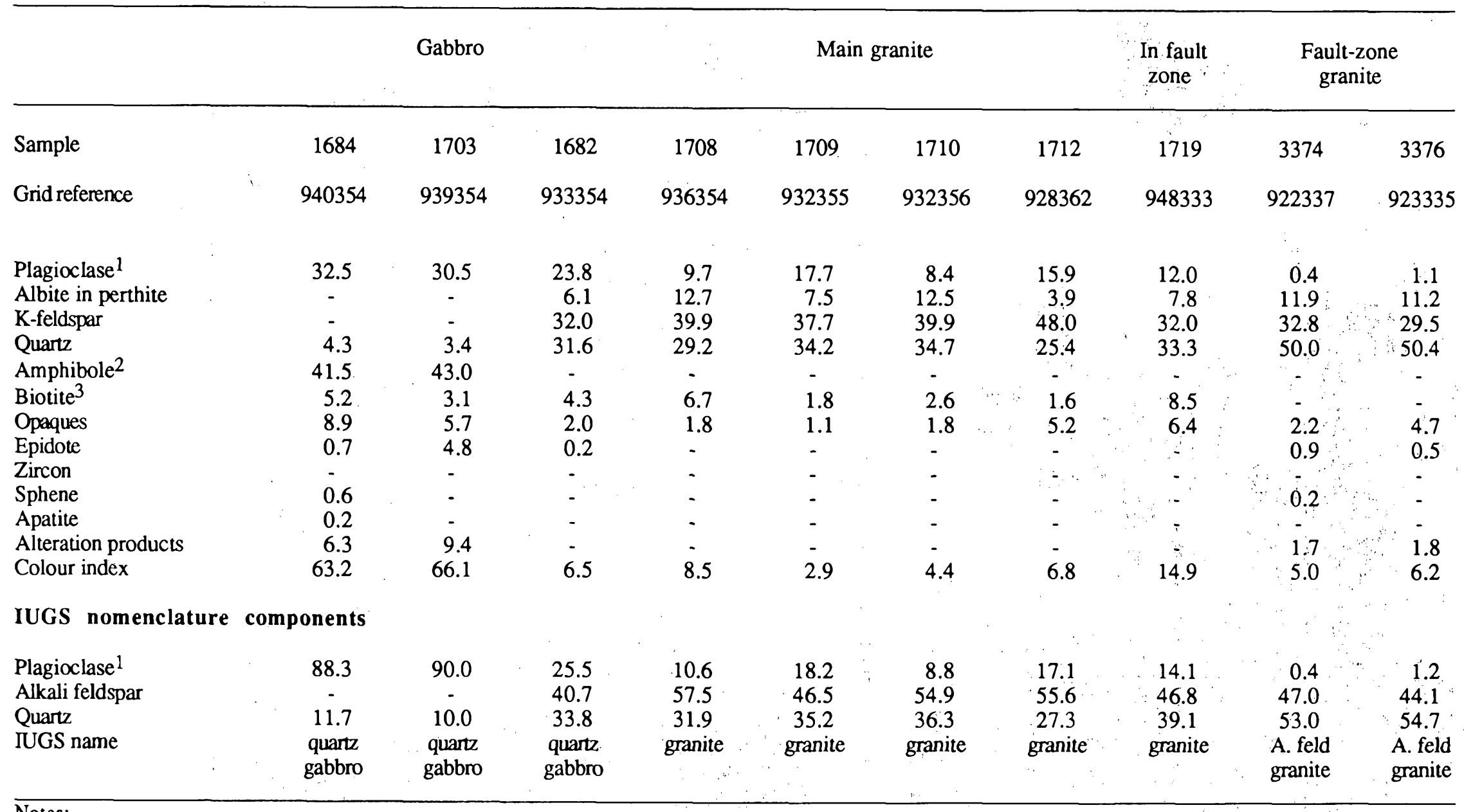

Notes:

${ }^{1}$ Individual crystals of plagioclase. In granite, mostly of albite composition.

2 Includes homblende and actinolite.

${ }^{3}$ Includes chlorite.

Modes are based on counting 1000 to 1500 points in one or two thin sections (depending on grain size of rock) stained using a modification of the method of Bailey and Stevens (1960) (M. Zentilli, personal communication, 1972). 


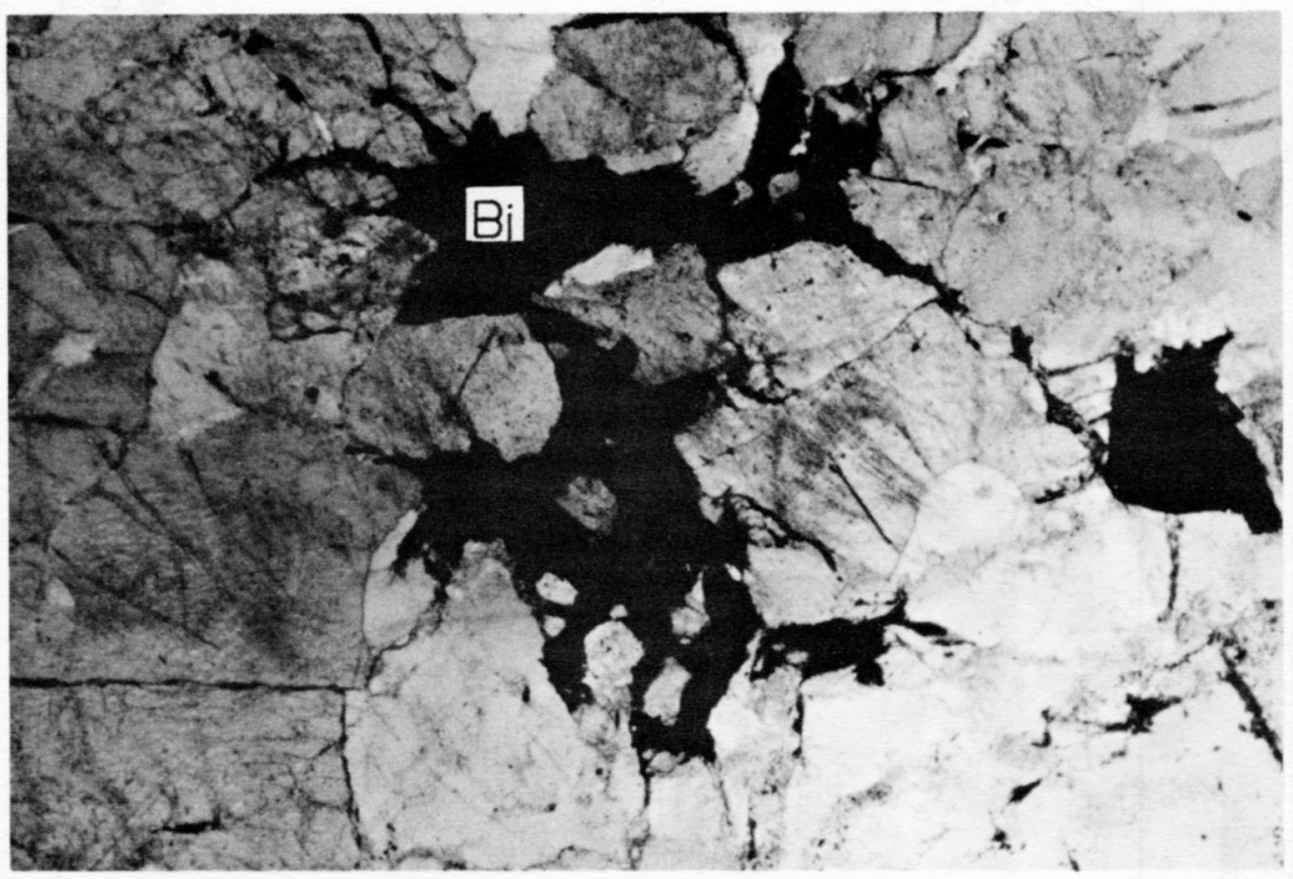

Plate1A. Ragged grains of secondary biotite (dark mineral) in granite (sample 1683), plane polarized light, field of view is 4.4 mm wide.

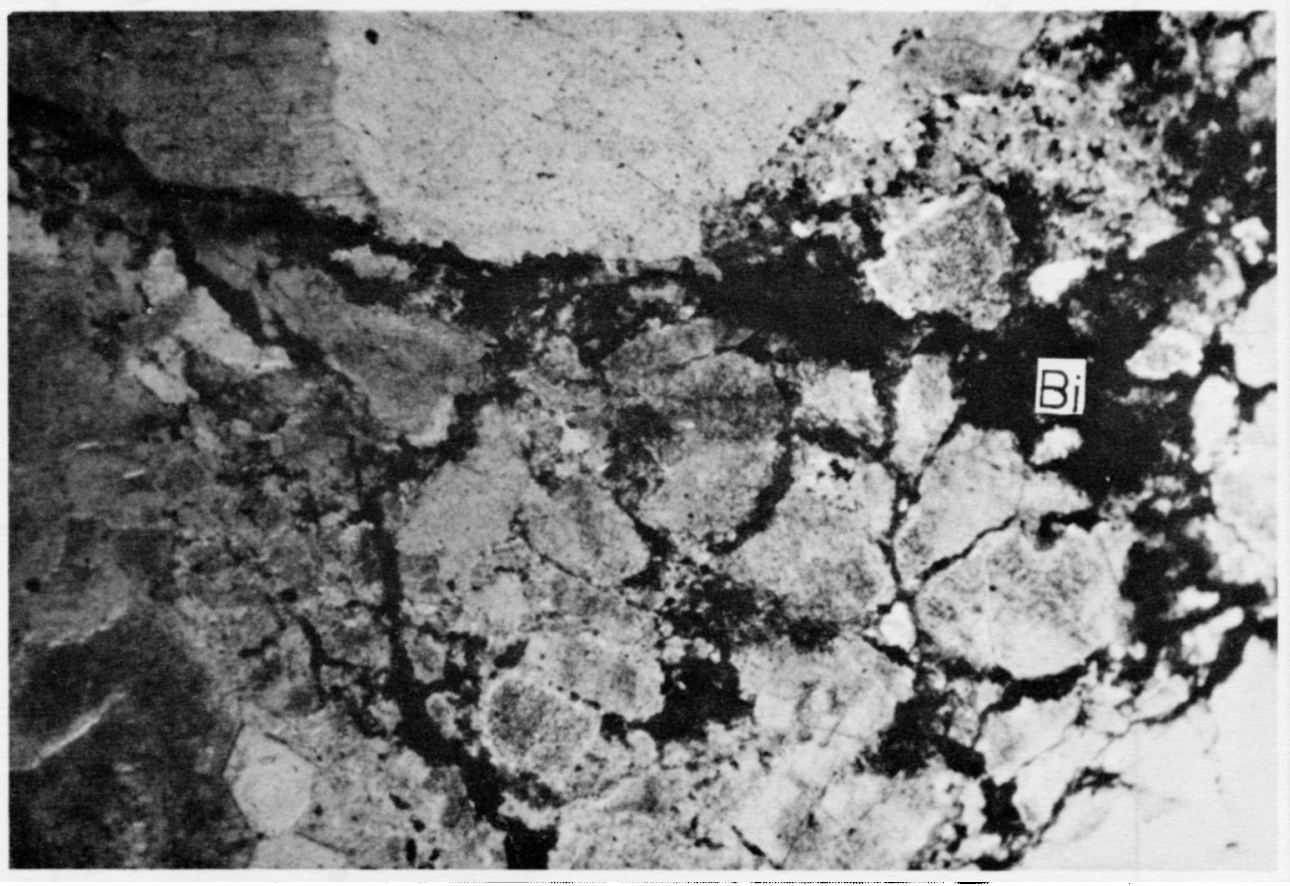

Plate1B. Vein-like clots of secondary biotite (dark mineral) along fractures in granite (sample 1681), plane polarized light, field of view is $2.7 \mathrm{~mm}$ wide. 
stage magmatic process, or it may be the result of later hydrothermal potassic metasomatism.

\section{The Hybrid Rocks}

The more mafic hybrid rocks have subophitic textures similar to the gabbros, but with lower color indices and higher proportions of interstitial quartz and K-feldspar. Clinopyroxene has been completely replaced by green homblende, biotite and penninite. Secondary biotite has also formed at the expense of homblende, and commonly contains $\mathrm{Fe}$-oxide inclusions which appear to follow relict homblende cleavage traces. Plagioclase is strongly altered to epidote and clay minerals. Quartz and minor $\mathrm{K}$-feldspar are present in the interstitial spaces, rarely showing graphic intergrowths. Brown biotite, interpreted to be primary, is locally present and usually contains oriented grains of rutile. Opaque minerals are fine-grained and anhedral occurring in clusters with hormblende, penninite and secondary biotite. Accessory minerals include zircon and sphene.

The more felsic hybrid rocks show granitic texture with minor development of mortar texture, suggesting that a small amount of strain has occurred. Feldspars occur both as individual grains and in perthite. Plagioclase twins are locally bent. In some samples, crystals with Rapakivi texture are present, whereas other samples (e.g., sample 3856 in Table 2) consist of $>90 \%$ albite. Some of these albite crystals show internal patterns resembling perthitic intergrowths, probably the result of albitization of magmatic perthites. Quartz is anhedral and weakly strained. Fine-grained masses of secondary biotite are fairly abundant. Anhedral, fine-grained opaque minerals commonly occur in clusters. Chlorite is present as radiating grains, commonly growing on opaque minerals. Other alteration minerals include epidote, actinolite and secondary biotite.

\section{Alkali feldspar granite in the Kirkhill fault zone}

South of the northemmost splay of the Kirkhill fault, the granite is leucocratic with very little igneous biotite and few free grains of plagioclase (Table 1). This fault-zone granite has a porphyroclastic texture and a totally recrystallized matrix of quartz and feldspar, locally with a strong fabric showing subhorizontal mineral lineation. The degree of deformation is very variable, and in places, the lineations appear rotated by later brittle motion. Porphyroclasts are mostly perthite, but also include strained quartz and rare plagioclase. The large porphyroclasts commonly have rims with extremely fine-grained mortar-texture. Relict granophyric textures are preserved in small patches. Opaque minerals are very fine-grained and occur in aggregates (probably recrystallized) which are commonly streaked out parallel to the fabric in the rock. Other minor minerals include chlorite and zircon, with rare muscovite, allanite and apatite. Local brittle deformation is also present, creating small cataclastic bands or microfaults. The predominantly ductile deformation contrasts with that north of the fault zone, where deformation consists of brittle fractures (many of which parallel the Kirkhill fault) and strained quartz disnupting the otherwise undisturbed granophyric texture. It also contrasts with the predominantly brittle deformation in the small areas of granite that petrographically resemble the main granite near the southern splay of the Kirkhill fault.

\section{Secondary biotite}

Most of the biotites in the main part of the Hanna Farm pluton differ from typical magmatic biotites in fresh granites of similar age elsewhere in the Cobequid Hills. They are greenishbrown in color and occur in tiny, flake-like crystal aggregates, forming vein-like clots that appear to have recrystallized (Plate 1). This greenish-brown biotite is interpreted to be secondary on the basis of its texture. Grains that appear to retain some primary component appear more brown and euhedral, whereas grains recognised as completely secondary on the basis of texture show various shades of green. Microprobe analyses have been made from the complete range of textural types of biotite (Table 3). These data show that the greener, completely secondary biotites are enriched in $\mathrm{Mg}$ and depleted in Ti compared with the browner samples with some primary component (e.g., analyses 1684a and $\mathrm{c}$ in Table 3). Similar trends have been reported by Jacobs and Parry (1979).

The presence of secondary biotite in vein-like clots along fractures and partial replacement of plagioclase by perthite are evidence of hydrothermal activity affecting the granites to the north after they had cooled sufficiently to deform in a brittle manner. Conversely, although there is evidence for britle deformation in the fault-zone granite, secondary biotite is absent. There is no evidence of replacement of plagioclase by perthite, although plagioclase content is so low that this is not conclusive. Thus the hydrothermal event which affected the main granite to the north of the fault zone appears to have been inactive in the fault zone.

Similar secondary biotite is found in Jeffers Group rocks and Carboniferous(?) mafic dykes immediately east of the pluton. Biotite from one of these mafic dykes intruded into the Jeffers Group $1 \mathrm{~km}$ east of the pluton yielded a K/Ar age of $303 \pm 11 \mathrm{Ma}$ (Pe-Piper and Piper, 1987), which may date this hydrothermal event.

\section{Geochemistry of the Hanna Farm pluton}

Chemical analyses of samples from the gabbro, hybrid rocks and granite of the main pluton are given in Table 2. Samples from the fault-zone granite were too deformed and weathered for reliable analysis. Based on chemical composition, the granite is alkali-feldspar granite (terminology of Streckeisen and LeMaitre, 1979) or granite (terminology of Barker, 1979). On the other hand, the hybrid rocks are monzonites (Streckeisen and LeMaitre) or granodiorites (Barker). The granite is probably not an S-type granite (Chappell and White, 1974) because it has high $\mathrm{Na}_{2} \mathrm{O}$, relatively low $\mathrm{Al}_{2} \mathrm{O}_{3}$, and lacks muscovite and metasedimentary xenoliths. The high $\mathrm{Na}_{2} \mathrm{O}$ and low $\mathrm{Al}_{2} \mathrm{O}_{3}$ is characteristic of I-type granites, and the $\mathrm{Ga} / \mathrm{Al}_{2} \mathrm{O}_{3}$ ratio is intermediate between typical I-type and A-type granites (Collins et al., 1982). The trace element composition of the granite is typical of within-plate granites, in terms of $\mathrm{Rb}, \mathrm{Nb}$ and $\mathrm{Y}$ as described by Pearce $\mathrm{e} t \mathrm{al}$. (1984). 
Table 2. Major and trace element analyses of representative rocks from the Hanna Farm pluton.

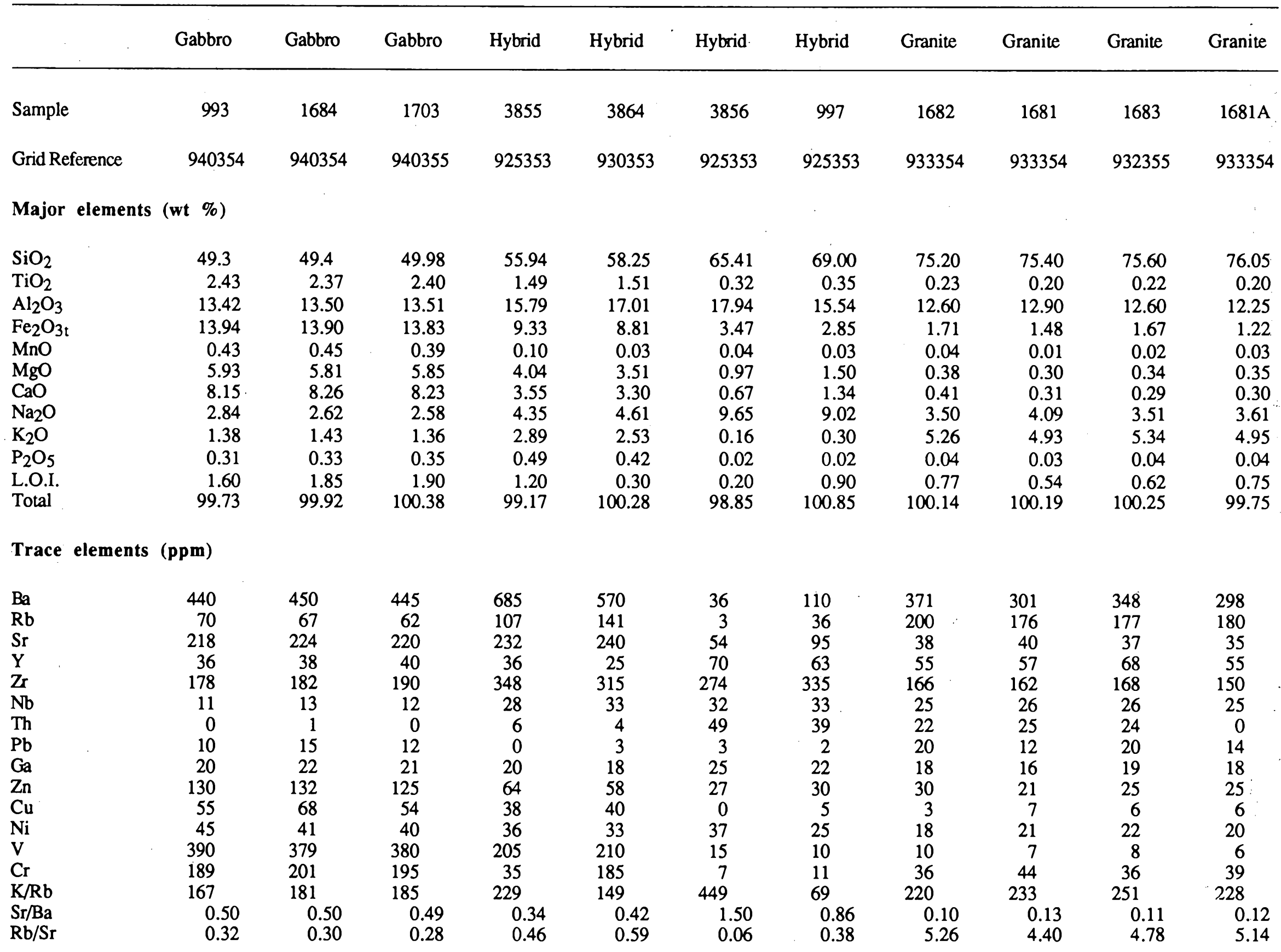




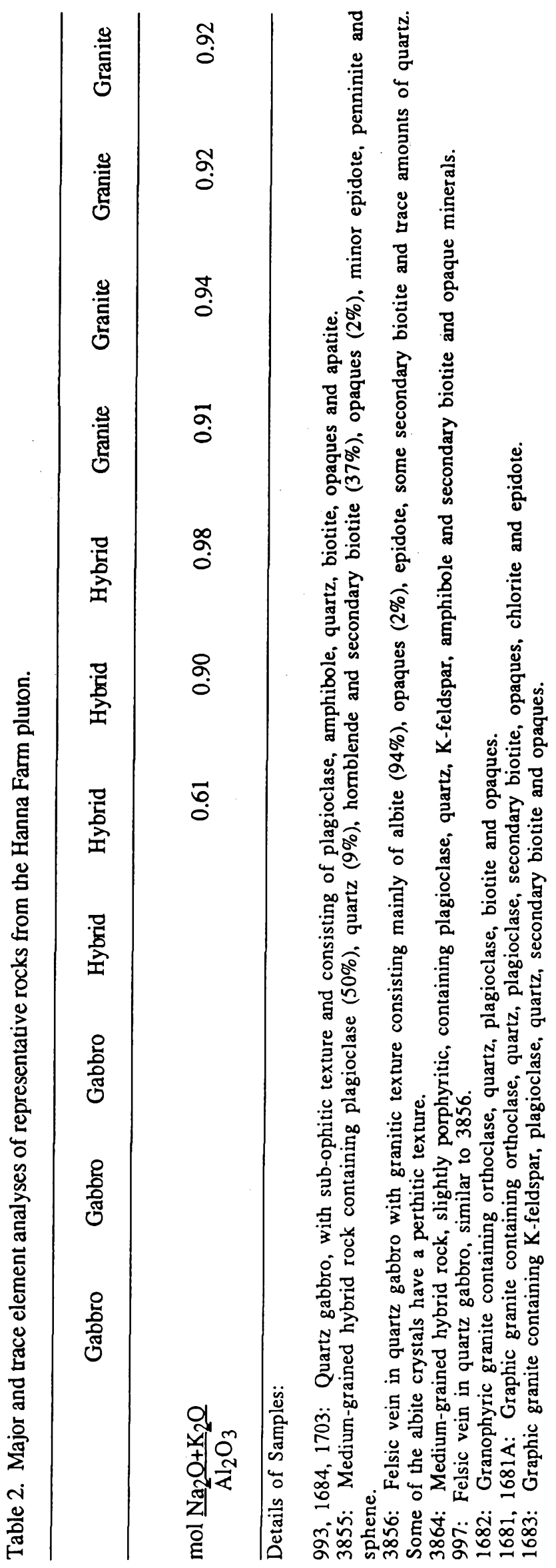

The gabbros are olivine tholeiites with high normative hypersthene. In their trace element compositions they resemble ocean-island tholeiites, with relatively high enrichment of $\mathrm{Ba}, \mathrm{Rb}$ and $\mathrm{K}$ relative to chondrites, and a lesser relative abundance of high field strength elements.

Harker diagrams (Figs. 4, 5) indicate the bimodal character of the pluton, the scatter in the compositions of the hybrid rocks and the small range of composition within the main granite.

Geochemically, the Hanna Farm pluton resembles other Early Carboniferous plutons in the western Cobequid Highlands (Pe-Piper et al., in press). The granite appears to have formed in a within-plate tectono-magmatic setting, and is predominantly Itype in character. Such features are probably associated with extension within the major strike-slip fault zone of the western Cobequid Highlands.

\section{Structural setting of the Hanna Farm pluton}

The northern part of the Hanna Farm pluton is a composite granite/gabbro pluton which has experienced hydrothermal alteration and growth of secondary biotite. Although outcrop is sparse, the pluton appears truncated at its southern margin by a series of east-west trending faults, which separate slices of deformed porphyroclastic granite with very few discrete plagioclase grains or secondary biotite. No granites offset by strike-slip motion that are petrographically comparable to the main granite have been mapped within or adjacent to the south side of the Kirkhill fault zone: the small outcrops of the main granite within the fault zone lie immediately south of the main pluton. This suggests that truncation of the main pluton probably took place by predominantly dip-slip motion, generally downdropping rocks to the south and uplifting rocks to the north. Donohoe and Wallace (1985) have shown that Carboniferous conglomeratic units derived from the Cobequid Highlands indicate intermittent vertical motion on major faults. The conglomeratic facies of the Greville River Formation preserved within the fault zone may indicate proximity to a bounding fault.

The petrographically distinct fault-zone granite might be due to large scale strike-slip movement along the northern-most fault, bringing in the porphyroclastic granite as an exotic slice after the hydrothermal event. This would require a remarkable juxtaposition of an exotic Carboniferous granite with an autochthonous Carboniferous granite, when similar lithologies are rare elsewhere along the Kirkhill fault zone.

More probably, the fault-zone granite was intruded separately from the main part of the Hanna Farm pluton, and suffered deformation within the fault zone. The hydrothermal fluids which altered the northern granites and surrounding country rock either predate, or were possibly associated with, this younger granite. This granite may have been intruded along an active fault zone, which would explain the change from brittle deformation to the north to ductile deformation within the fault zone, particularly if deformation took place before the fault-zone granite had cooled completely. The lineations indicate strike-slip motion, yet mapping shows that there is less than $1 \mathrm{~km}$ lateral offset of granite within the Kirkhill fault zone, suggesting that strike-slip movement on the fault zone following granite intrusion was only minor. 
Table 3. Representative electron microprobe analyses of biotites.

\begin{tabular}{|c|c|c|c|c|c|c|c|c|c|}
\hline & \multicolumn{2}{|c|}{$\begin{array}{c}\text { Mafic dyke } \\
1159\end{array}$} & \multicolumn{3}{|c|}{$\begin{array}{c}\text { Gabbro } \\
1684\end{array}$} & \multicolumn{2}{|c|}{$\begin{array}{c}\text { Hybrid rock } \\
3855\end{array}$} & \multicolumn{2}{|c|}{$\begin{array}{c}\text { Granite } \\
1681\end{array}$} \\
\hline & & & a & $\mathrm{b}$ & c & & & & \\
\hline Colour & green & green & $\begin{array}{l}\text { green- } \\
\text { brown }\end{array}$ & $\begin{array}{l}\text { green- } \\
\text { brown }\end{array}$ & brown & green & green & green & green \\
\hline $\mathrm{SiO}_{2}$ & 39.10 & 38.71 & 34.03 & 35.61 & 36.24 & 36.06 & 36.50 & 38.15 & 37.69 \\
\hline $\mathrm{TiO}_{2}$ & - & 1.25 & 0.96 & 1.75 & 2.69 & 0.87 & 1.47 & 0.59 & 1.28 \\
\hline $\mathrm{Al}_{2} \mathrm{O}_{3}$ & 15.48 & 15.82 & 15.50 & 14.76 & 14.52 & 15.91 & 14.86 & 16.31 & 16.64 \\
\hline $\mathrm{FeO}_{\mathrm{t}}$ & 16.51 & 18.17 & 22.91 & 23.25 & 23.21 & 20.97 & 20.64 & 18.06 & 18.10 \\
\hline $\mathrm{MnO}$ & - & - & 0.32 & 0.24 & 0.26 & 0.23 & 0.18 & 0.05 & 0.09 \\
\hline $\mathrm{MgO}$ & 14.27 & 12.56 & 12.34 & 10.32 & 9.37 & 11.17 & 11.09 & 12.53 & 11.50 \\
\hline $\mathrm{CaO}$ & - & 0.07 & 0.11 & 0.06 & 0.01 & 0.06 & 0.08 & 0.07 & 0.06 \\
\hline $\mathrm{Na}_{2} \mathrm{O}$ & - & - & 0.10 & 0.11 & 0.01 & 0.11 & 0.13 & - & - \\
\hline $\mathrm{K}_{2} \mathrm{O}$ & 9.57 & 9.46 & 6.26 & 8.90 & 9.53 & 9.30 & 9.14 & 9.41 & 9.32 \\
\hline Total & 94.93 & 96.03 & 92.53 & 95.00 & 95.84 & 94.68 & 94.07 & 95.29 & 94.68 \\
\hline
\end{tabular}

Details of samples:

1159: Mafic dyke cutting Jeffers Group at lower end of Jeffers Brook. Greenish biotite, which has been dated at $303 \pm 11 \mathrm{Ma}$.

1684: Gabbro. a,b - small greenish brown crystals of biotite; c - brownish anhedral biotite crystal, probably igneous.

3855: Hybrid rock with olive green flakes of biotite.

1681: Graphic granite with olive-green flakes of biotite.

\section{THE KIRKHILL FAULT}

\section{Description of the Kirkhill fault}

The strategic position of the Hanna Farm pluton across the Kirkhill fault zone provides constraints on the history of motion on this important fault. In the area east of the Hanna Farm pluton, between highway 2 and Davidson Brook, the Kirkhill fault zone is several hundred metres wide and is marked by a zone of intensely mylonitized felsic pyroclastic rocks of the Jeffers Group and granodiorite of the Davidson Brook pluton (Fig. 3). The plutonic rocks are petrographically and geochemically similar to dated late Hadrynian rocks of the Jeffers Brook and McCallum Settlement plutons (Clarke et al., 1980; Donohoe and Wallace, 1985). Rhyolites of the Fountain Lake Group outcrop to the south of the fault zone and, in an area of sparse outcrop, also appear to onlap the fault zone to the east. They show no ductile deformation, but outcrop is insufficient to determine whether any brittle deformation has occurred. Mylonitic fabrics in late Hadrynian rocks of the Kirkhill fault zone are irregular, with stretching lineations trending from approximately $020^{\circ}$ to $130^{\circ}$, suggesting local rotation of fabrics after mylonitisation.

The trend of the Kirkhill fault zone appears to be offset from the Davidson Brook area to the area south of the Hanna Farm pluton; a north-south trending fault through the Parrsboro Gap is postulated to have produced this offset (Fig. 3). Similar offsets have been mapped elsewhere along the Cobequid Fault zone by Donohoe and Wallace $(1982,1985)$. Although outcrop is sparse, the Kirkhill fault appears to truncate the main granite of the Hanna Farm pluton. Continuation of this granite within the Kirkhill fault zone or to the south has not been recognised; this suggests that truncation was principally by dip-slip rather than strike-slip motion. The fault-zone granite is not intensely mylonitised: rather, there is only a subhorizontal stretching of quartz. The stretching lineation in the fault-zone granite is sub-horizon$\mathrm{tal}$, and as in other areas shows a variety of trends.

On Kirkhill Mountain, in the Diligent River area west of the Hanna Farm pluton, the Kirkhill fault zone is made up of several parallel, distinct faults (Fig. 3). Rocks within the fault zone are cataclastically deformed, and comprise a variety of lithologies: diorite similar to the Hadrynian Jeffers Brook pluton and granite similar to the Hadrynian McCallum Settlement granite in the eastern Cobequid Hills (both described by Clarke et al., 1980 and Donohoe and Wallace, 1982), together with sedimentary rocks similar to the Cranberry Lake Formation and volcanic and pyroclastic rocks similar to the Gilbert Hills Formation of the late Hadrynian Jeffers Group (Pe-Piper and Piper, in press). The rocks are locally mylonitised, but again there is substantial variation in the trend of stretching lineations (from $100^{\circ}$ to $170^{\circ}$ ). The fault here marks the northern edge of the Devono-Carbonif- 

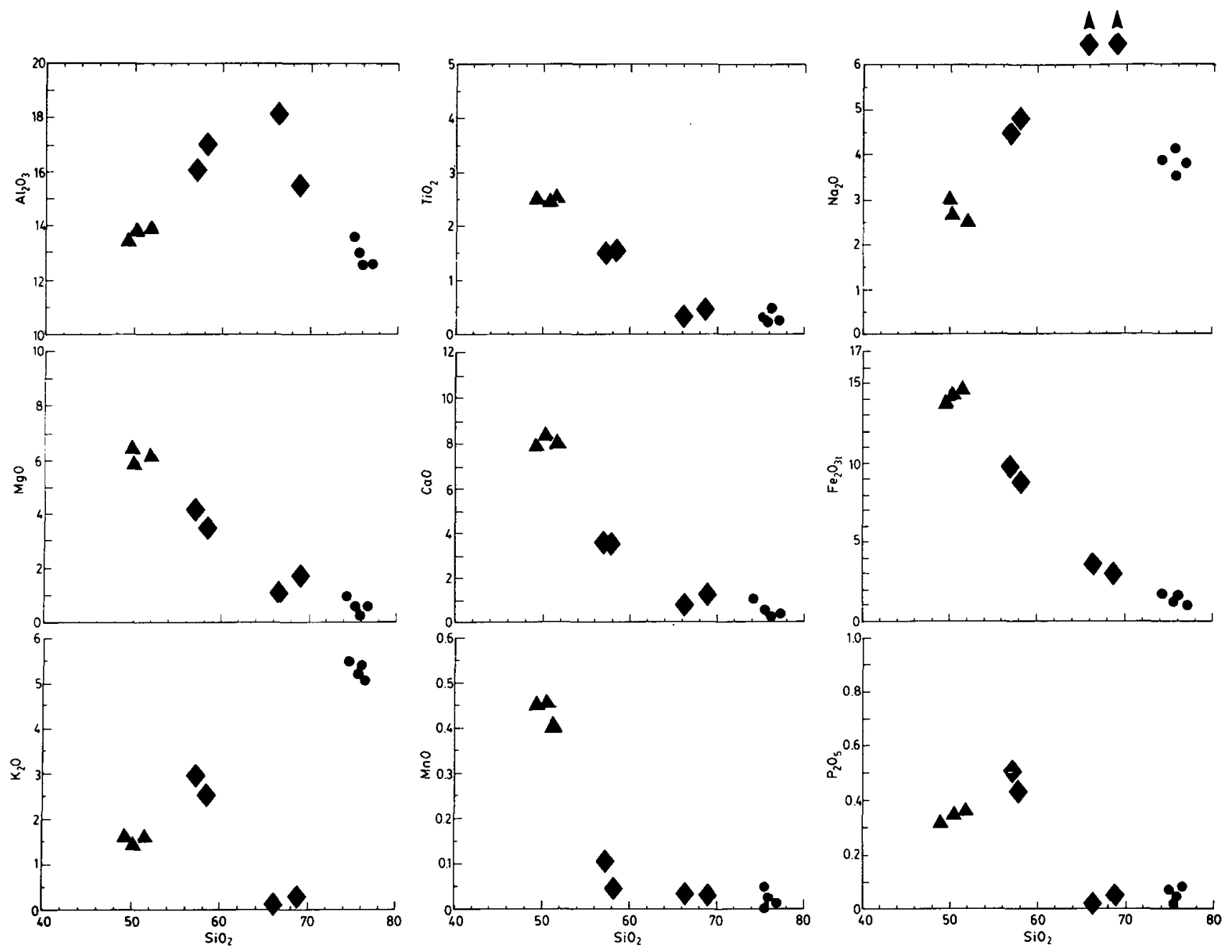

Fig. 4. Major element variations within the Hanna Farm pluton samples. Triangles indicate gabbros; diamonds indicate hybrids; dots indicate granites.

erous sedimentary rocks of the Greville River Formation, suggesting that there may be a significant component of dip-slip motion, which may either be a component of the predominant horizontal offset, or represent a distinct predominantly vertical event (Donohoe and Wallace, 1985). The fault zone is onlapped west of Ramshead River (Fig. 3) by the apparently undeformed rocks of the Cumberland Group of late Westphalian B - early C age (Donohoe and Wallace, 1982), although outcrop is insufficient to exclude the presence of local minor brittle deformation.

\section{Possible westward continuation of the Kirkhill fault}

In the Fowler Brook inlier (Fig. 1), mylonitised rhyolitic lavas or felsic tuffs of the Jeffers Group are in faulted contact with mylonitised granite of the Apple River pluton. This pluton is petrographically and geochemically similar to dated Early Carboniferous plutons of the western Cobequid Highlands (Pe-Piper et al., in press). Zones of polymict cataclasites cut the southem part of the Jeffers Group in this area, once again bringing the Jeffers Group in contact with the Greville Formation. The mylonitic stretching lineation is oriented to $235^{\circ}$ with a plunge of about $10^{\circ}$.

The Cape Chignecto pluton, which is cut by the Cobequid
Fault, extends across any linear projected continuation of the Kirkhill fault. It is possible that the Kirkhill fault bends southwards and merges with the Cobequid Fault, which is also a subvertical, predominantly strike-slip fault. The Cape Chignecto pluton shows a flat-lying mylonitic fabric (indicating a northwest-directed sense of thrusting) that was developed within 20 million years of intrusion of the pluton and was subsequently rotated along local fault zones including the Cobequid Fault (Piper et al., 1988). This fabric indicates a northwest-directed sense of thrusting.

\section{Possible eastward continuation of the Kirkhill fault}

The Kirkhill fault cannot be conclusively recognised east of Davidson Brook. Such a major strike-slip fault zone should show continuity. There are two lineaments that are candidates for the eastward extension of the fault: each is recognised from predominantly vertical motions which may mask earlier predominantly strike-slip motion. One marks the contact of the Fountain Lake Group with the Jeffers Group to the north, and continues through a zone of faulting just north of the northern limit of the North River pluton. It is marked by a prominent vertical fault in West Harrington River, but north of the North River pluton, the 

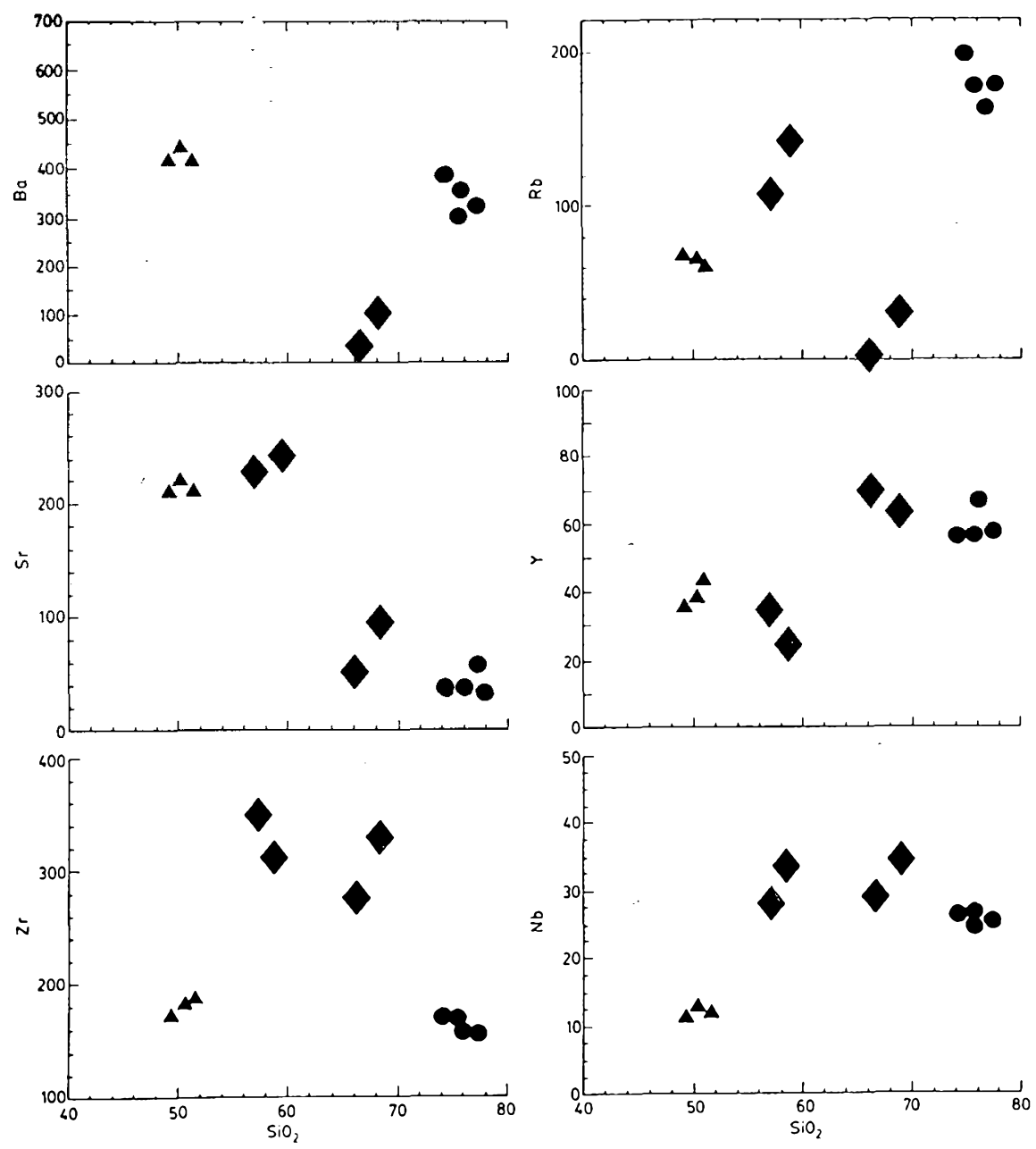

Fig. 5. Selected trace element variations within the Hanna Farm pluton samples. Symbols as in Figure 4.

predominant deformational structures are flat-lying. The other lineament is a series of faults cutting Jeffers Group rocks in McCarthy Brook and south of the North River pluton. If this is the continuation of the Kirkhill fault, then its continuity through the Jeffers Group inlier north of the West Moose River pluton is uncertain: east-west trending vertical structures are not seen in this area.

\section{Discussion}

In summary, the Kirkhill fault is several hundred metres wide and cuts and mylonitises rocks of Late Precambrian age. The probable westerly continuation of the fault is marked by mylonites, which indicate sub-horizontal strike-slip motion, deforming the Jeffers Group and the (probable) Early Carboniferous Apple River pluton. The Early Carboniferous Cape Chignecto pluton shows flat-lying northwest-directed ductile deformation which may be related to this period of motion. $\mathrm{A} \mathrm{Rb} / \mathrm{Sr}$ isochron of $349 \pm 12$ Ma was obtained from least deformed rocks of the Cape Chignecto pluton (Pe-Piper et al., in press). The fault appears to truncate the southern margin of the main northern part of the Hanna Farm pluton (dated at $338 \pm 17 \mathrm{Ma}$ ). The fault did not result in ductile deformation in the Fountain Lake Group rhyolites. Rhyolites $10 \mathrm{~km}$ east of Davidson Brook have been dated by the Rb-Sr method, and along with other samples from farther east fall on an isochron of $341 \pm 4 \mathrm{Ma}$ (Cormier, 1982). The southern part of the Hanna Farm pluton (plagioclase-free granite phase) within the Kirkhill fault zone shows no significant horizontal offset and only slight ductile deformation. The fault appears to be onlapped by Westphalian sediments (about 305 Ma).

\section{CONCLUSIONS}

The Hanna Farm pluton is a composite granite-gabbro pluton. Gabbro occurs in two stocks at the edge of the main pluton. Hybrid rocks are developed at the contacts with the granite. Granitic hybrid rocks cut gabbroic hybrid rocks, suggesting that the two magmas were essentially synchronous. The granite is a within-plate granite with I-type characteristics, probably associated with extension along the strike-slip fault systems of the western Cobequid Highlands.

The following sequence of events is inferred for the Kirkhill fault:

(1) Predominantly strike-slip motion producing mylonitisation of late Hadrynian rocks and the probable Early Carboniferous Apple River pluton. The major mylonitisation of the Cape Chignecto pluton might be associated with this motion. Whether there was significant pre-Carboniferous motion is not known.

(2) Intrusion of the main Hanna Farm pluton, dated at $338 \pm 17$ $\mathrm{Ma}$, immediately north of the Kirkhill fault. 
(3) Brittle deformation of the main pluton, and alteration of the pluton and country rock by hydrothermal fluids. Some of the rotation of mylonitic fabrics in parts of the fault zone may have occurred at this time. Dip-slip motion may have truncated the southern margin of the main pluton producing part of the observed vertical motion on the Kirkhill fault zone. Hydrothermal biotite has been dated at $303 \pm 11 \mathrm{Ma}$. There is little or no deformation of Fountain Lake Group dated at $341 \pm 4 \mathrm{Ma}$ and of the Westphalian B-C Cumberland Group (305 Ma).

(4) Intrusion of leucocratic granite in the fault zone. The age of this granite is unknown, although it is petrographically similar to some granite from the Pleasant Hills pluton ( $315 \pm 25 \mathrm{Ma})$.

(5) Minor strike-slip motion on the Kirkhill fault zone to produce the deformation in the fault-zone granite, but little deformation of the Fountain Lake and Cumberland groups.

(6) Offset of the Kirkhill fault zone by northwest-trending faults, and probable further dip-slip motion; part of this motion is probably of Mesozoic age (Donohoe and Wallace, 1985).

\section{ACKNOWLEDGEMENTS}

This work was supported by an NSERC operating grant. We thank D.J.W. Piper, M. Blank and G. Chinn for assistance in the field. Analytical work was carried out at the St Mary's regional $\mathrm{X}$-ray fluorescence centre and the Dalhousie regional microprobe laboratory. We thank H.V. Donohoe for his support of this project and Donohoe and J. Hill for helpful reviews.

BAILEY, E.H. and STEVENS, R.E. 1960. Selective staining of Kfeldspar and plagioclase on rock slabs and thin sections. American Mineralogist, 45, pp. 1020-1025.

BARKER, F. 1979. Trondhjemite: definition, environment and hypotheses of origin. In Trondhjemites, dacites and related rocks. Edited by F. Barker. Elsevier, New York, pp. 1-12.

CHAPPELL, B.W. and WHITE, A.J.R. 1974. Two contrasting granite types. Pacific Geology, 8, pp. 173-174.

CLARKE, D.B. 1976. Petrological applications of microbeam techniques. In Short course on Microbeam Techniques. Edited by D.G.W. Smith. Mineralogical Association of Canada.

CLARKE, D.B., BARR, S.M., and DONOHOE, H.V. 1980. Granitoid and other plutonic rocks of Nova Scotia. In The Caledonides in the U.S.A. Proceedings of the IGCP, Memoir 2, pp. 107-116.

COLLINS, W.J., BEAMS, S.D., V.HITE, A.J.R., and CHAPPELL, B.W. 1982. Nature and origin of A-type granites with particular reference to southeastern Australia. Contributions to Mineralogy and Petrology, 80, pp. 189-200.

CORMIER, R.F. 1979. Rubidium/strontium isochron ages of Nova Scotia granitoid plutons. Nova Scotia Department of Mines, Report 79-1, pp. 143-148.

- 1982. Rb/Sr age data for the Fountain Lake Group volcanics. Nova Scotia Department of Mines and Energy, Report 82-1, pp. 114-115.

DONOHOE, H.V. 1976. The Cobequid Mountains Project.
Nova Scotia Department of Mines, Report 76-2, pp. 113-124.

DONOHOE, H.V. and WALLACE, P.I. 1982. Geological map of the Cobequid Highlands, Nova Scotia. Scale 1:50,000. Nova Scotia Department of Mines and Energy.

- 1985. Repeated orogeny, faulting and stratigraphy in the Cobequid Highlands, Avalon Terrane of northern Nova Scotia. Excursion 3, Geological Association of Canada - Mineralogical Association of Canada Joint Annual Meeting, Fredericton, New Brunswick, $77 \mathrm{p}$.

DONOHOE, H.V., HALLIDAY, A.N., and KEPPIE, J.D. 1986. Two $\mathrm{Rb}-\mathrm{Sr}$ whole rock isochrons from plutons in the Cobequid Highlands, Nova Scotia, Canada. Maritime Sediments and Atlantic Geology, 22, pp. 148-154.

EISBACHER, G.H. 1969. Displacement and stress field along part of the Cobequid Fault, Nova Scotia. Canadian Joumal of Earth Sciences, 6, pp. 1095-1104.

1970. Deformation mechanics of mylonitic rocks and fractured granites in the Cobequid Mountains, Nova Scotia, Canada. Geological Society of America Bulletin, 81, pp. 2009-2020.

JACOBS, D.C. and PARRY, W.T. 1979. Geochemistry of biotite in the Santa Rita porphyry copper deposit, New Mexico. Economic Geology, 74, pp. 860-887.

KEPPIE, J.D. 1982. The Minas geofracture. In Major structural zones and faults of the Northern Appalachians. Edited by P. St. Julien and J. Béland. Geological Association of Canada, Special Paper 24, pp. 263-280.

PEARCE, J.A., HARRIS, N.B.W., and TINDLE, A.G. 1984. Trace element discrimination diagrams for tectonic interpretation of granitic rocks. Joumal of Petrology, 25, pp. 952-983.

PE-PIPER, G., CORMIER, R.F., and PIPER, D.J.W. In press. The age and significance of Carboniferous plutons of the Westem Cobequid Hills, Nova Scotia. Canadian Journal of Earth Sciences.

PE-PIPER, G. and PIPER, D.J.W. 1987. The pre-Carboniferous rocks of the westem Cobequid Hills, Avalon Zone, Nova Scotia. Maritime Sediments and Atlantic Geology, 23, pp. 41-48.

- In press. The Late Hadrynian Jeffers Group, Cobequid Highlands, Avalon Zone of Nova Scotia: a back-arc volcanic complex. Bulletin of the Geological Society of America.

PIPER, D.J.W., WALDRON, J.W.F., and PE-PIPER, G. 1988. Deformation of the Cape Chignecto pluton, western Cobequids: a record of Avalon-Meguma convergence? Geological Association of Canada - Mineralogical Association of Canada Joint Annual Meeting, Program with Abstracts, 13, p. 99.

RYAN, R.J., CALDER, J.H., DONOHOE, H.V., Jr., and NAYLOR, R. 1987. Late Paleozoic sedimentation and basin development adjacent to the Cobequid Highlands massif, eastern Canada. Canadian Society of Petroleum Geologists, Memoir 12, pp. 311-317.

STRECKEISEN, A. 1976. To each plutonic rock its proper name. Earth Science Reviews, 12, pp. 1-33.

STRECKEISEN, A. and LEMAITRE, R.W. 1979. A chemical approximation to the Modal QAPF classification of the igneous rocks. Neues Jahrbuch fur Mineralogie, Abhandlungen, 136-2, pp. 169 206.

YEO, G.M. and GAO, R-X. 1987. Stellarton graben: an upper Carboniferous pull-apart basin in northern Nova Scotia. Canadian Society of Petroleum Geologists Memoir, 12, pp. 299-309. 